\title{
Effect of NPK Fertilization in the Newly Reclaimed Soil on Productivity of Grain Sorghum
}

\author{
Soliman, Eman M.A. ${ }^{1}$; R.A. Dawood ${ }^{2}$; I.A. El-Far ${ }^{2}$ and M.I. Bashir ${ }^{3}$ \\ ${ }^{1}$ Agric. Res. Station at Arab El-Awamer, Assiut Governorate. \\ ${ }^{2}$ Agronomy Dept., Fac. Agric., Assiut Univ. \\ ${ }^{3}$ ARC, FCRI, Sorghum Res. Department, Giza, Egypt
}

Received on: $17 / 11 / 2016$

Accepted for publication on:21/11/2016

\section{Abstract}

A field experiment was conducted in the Agricultural Research Station at Arab El-Awamer, Assiut Governorate, during the two growing seasons of 2014 and 2015 to investigate the effect of NPK fertilization in newly reclaimed soil on grain sorghum productivity. The randomized complete block design using splitsplit-plot with four replications was arrangement, where nitrogen fertilizer rates (100, 120 and $140 \mathrm{~kg} \mathrm{~N} /$ fed. i.e. $\mathrm{N}_{1}, \mathrm{~N}_{2}$ and $\mathrm{N}_{3}$, respectively) were allocated in the main plots, while phosphorus fertilizer rates $\left(22.5\right.$ and $30 \mathrm{~kg} \mathrm{P}_{2} \mathrm{O}_{5} /$ fed. i.e. $\mathrm{P}_{\mathbf{1}}$ and $\mathrm{P}_{2}$, respectively) were assigned in the sub-plots and potassium fertilizer rates (24 and $36 \mathrm{~kg} \mathrm{~K} \mathrm{~K}_{2} \mathrm{O} /$ fed. i.e. $\mathrm{K}_{1}$ and $\mathrm{K}_{2}$, respectively) were fixed in the sub-subplots. The grains of sorghum Hybrid 305 was sown on $13^{\text {th }}$ and $17^{\text {th }}$ June in the first and second seasons, respectively. The plot area was $12 \mathrm{~m}^{2}$ including 4 ridges of $60 \mathrm{~cm}$ apart with $4 \mathrm{~m}$ length. The results could be summarized as the following:

- The plant height in both seasons and the panicle length, 1000 grain weight and grain yield/fed. in the second season only, were increased with increasing $\mathrm{N}$ fertilizer rates up to $120 \mathrm{~kg} \mathrm{~N} / \mathrm{fed}$., as well as the highest mean values for panicle width, grains weight/panicle in both season and panicle length, 1000 grain weight and grain yield/fed. in the first season were recorded by $100 \mathrm{~kg} \mathrm{~N} / \mathrm{fed}$.

- Also, the mean values for all the studied traits were increased by increasing P fertilizer rates in both seasons.

- Here too, the lowest $\mathrm{K}$ fertilizer rate $\left(24 \mathrm{~kg} \mathrm{~K}{ }_{2} \mathrm{O} /\right.$ fed. $)$ gave the highest mean values of grains weight/panicle, 1000-grain weight and grain yield/fed. in the first season, while the highest $\mathrm{K}$ fertilizer rate $(36 \mathrm{~kg} \mathrm{~K} 2 \mathrm{O} /$ fed.) gave the highest mean values for the same traits in the $2^{\text {nd }}$ season.

- In general, the first order interaction either $\mathrm{N}_{3} \mathrm{xP}_{1}$ or $\mathrm{N}_{3} \mathrm{xP}_{2}$ and $\mathrm{N}_{3} \mathrm{xK}_{1}$ or $\mathrm{N}_{3} \mathrm{xK}_{2}$ as well as $\mathrm{P} 1 \mathrm{xK} 1$ or $\mathrm{P} 1 \mathrm{xK} 2$ interaction treatments gave the lowest mean values for all the studied traits.

- Also, the maximum grain yield/fed. (21.46 and 22.78 ard.) were recorded by $\mathrm{N}_{1} \times \mathrm{P}_{2} \mathrm{xK}_{1}$ and $\mathrm{N}_{2} \mathrm{xP}_{2} \mathrm{xK}_{1}$ interaction treatments in the $1^{\text {st }}$ and $2^{\text {nd }}$ seasons, respectively.

Keywords: Sorghum, NPK fertilization rates, and yield and its components.

\section{Introduction}

Sorghum is the fifth most important cereal crop grown for animal and human consumption in the world.
In Egypt, reclaimed soils are often deficient in $\mathrm{N}, \mathrm{P}$ and $\mathrm{K}$, hence response to the three mineral fertilizers is universal. Nitrogen, phosphorus 
and potassium are the essential elements required for plant growth in relatively large amounts. However, deficiencies of nitrogen and phosphorus are common. Fertilizers are an efficient exogenous source of plant nutrient. In Egypt, fertilizer use is insufficient and imbalanced. Balanced fertilizer use can help reverse environmental degradation by providing much needed nutrients to soil, thereby increasing crop yields. Shortriya (1998) reported that balanced application of NPK caused an increase in sorghum yield up to $122 \%$ of the recorded, in India. Here too, nutrient inputs from chemical fertilizers are needed to replace nutrient are exported and last during cropping, to maintain positive nutrient balances (Bauh and Mwinkaard, 2009). Many studied have been published on $\mathrm{N}, \mathrm{P}$ or $\mathrm{K}$ fertilizer response in sorghum (Varvel \& Wilhelm, 2003 and Kayuki et al., 2007), but these studied were limited to single nutrients and did not include a combination of nutrients. Alike, Allam et al. (2002) stated that the application of nitrogen fertilizer exerted a significant influence on panicle weight, seed index and grain yield/fed. of sorghum. Ashiono et al. (2005) confirmed that nitrogen level beyond $40 \mathrm{~kg} / \mathrm{ha}$ and phosphorus level beyond $30 \mathrm{~kg} / \mathrm{ha}$ did not increase plant height, seed weight and grain yield. They added that the optimum sorghum grain yield was attained at $40 \mathrm{~kg} \mathrm{~N} / \mathrm{ha}$ and $20 \mathrm{~kg}$ $\mathrm{P}_{2} \mathrm{O}_{5} /$ ha. El-Aref et al. (2005) reported that grain sorghum cultivars affected significantly by nitrogen fertilization and increase panicle weight, 1000 grain weight and grain yield. Akram et al. (2007) declared that $\mathrm{P}$ enhanced the crop growth and yield more than $\mathrm{K}$ and the best results were observed with their combined application. Moreover, maximum biological and grain yield of sorghum were 31.7 and $2.26 \mathrm{t} /$ ha under $\mathrm{P}+\mathrm{K}$. Miko and Manga (2008) declared that nitrogen significantly influenced on plant height and grain yield. Afzal et al. (2012) noted that the plant height was increased by increasing nitrogen levels. Buah et al. (2012) cleared that fertilizer $\mathrm{N}, \mathrm{P}$ and $\mathrm{K}$ did not show significant interactions for any parameter, across years, added $\mathrm{K}$ did not influence grain yield and yield components. However, $\mathrm{P}$ increased yield by $14 \%$ and $\mathrm{N}$ effected yield in a quadratic manner. Abou-Amer \& Kewan (2014) reported that application of the highest rates of $\mathrm{N}(40 \mathrm{~kg}$ $\mathrm{N} /$ fed.) and $\mathrm{P}\left(40 \mathrm{~kg} \mathrm{P}_{2} \mathrm{O}_{5} /\right.$ fed. $)$ increased grain sorghum yields. Ayat et al. (2014) found that the application of NPK fertilizers exerted a significant influence on plant height, panicle weight, seed index and grain yield/fed. of sorghum and the maximum mean values for these traits were obtained by $125 \% \mathrm{NPK} /$ fed. of the recommended fertilizers $(100,31$ and 24 unit/fed. N, P and K, respectively) in both seasons. Zand et al. (2014) concluded that the effect of nitrogen application rate was significant for grain yield, but it did not significant for 1000 grain weight.

Gebremariam and Assefa (2015) cleared that application of $\mathrm{N}$-fertilizer significantly increased plant height, panicle length, yield per panicle, 1000 grain weight and grain yield over the control. Highest responses of these parameters were obtained with application of $150 \mathrm{~kg} \mathrm{~N} / \mathrm{ha}$. 
Sujathamma et al. (2015) showed that application of $100 \%$ recommended dose of fertilizer $\left(\mathrm{N}_{-} \mathrm{P}_{2} \mathrm{O}_{5^{-}}\right.$ $\mathrm{K}-80-40-40)$ to sorghum plants recorded the highest mean values for panicle length, and grain yield/ha.

To achieve higher yield of crops, it is essential to provide them the optimum level of their nutrients requirements. Therefore, present study was conducted to determine the response of grain sorghum to application of combined $\mathrm{N}, \mathrm{P}$ and $\mathrm{K}$ fertilizer in newly reclaimed soil.

\section{Materials and Methods}

The present investigation was carried out in the Agricultural Research Station at Arab El-Awammer in Assiut Governorate, during the two growing season of 2014 and 2015 to study the effect of NPK fertilization in newly reclaimed soil on the productivity of grain sorghum. The soil used for these experiments was sandy and its structure as presented in Table 1.

Table 1. The average physical and chemical analysis of the experimental site before cultivation in both seasons.

\begin{tabular}{|c|c|c|c|c|c|c|c|c|c|c|}
\hline \multicolumn{11}{|c|}{ Physical properties: } \\
\hline \multicolumn{3}{|c|}{$\begin{array}{c}\text { Particle size distribution } \\
(\%)\end{array}$} & \multirow{2}{*}{\multicolumn{2}{|c|}{$\begin{array}{l}\text { Texture } \\
\text { class }\end{array}$}} & \multirow{2}{*}{$\begin{array}{l}\text { O.M } \\
(\%)\end{array}$} & \multirow{2}{*}{$\begin{array}{c}\mathrm{CaCO}_{3} \\
(\%)\end{array}$} & \multicolumn{3}{|c|}{$\begin{array}{l}\text { Moisture content } \\
\text { (volumetric \%) }\end{array}$} & \multirow{2}{*}{$\begin{array}{l}\text { A.W } \\
(\%)\end{array}$} \\
\hline Sand & Silt & Clay & & & & & S.P. & F.C. & W.P & \\
\hline 89.9 & & & 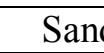 & & 0.25 & 30.9 & 23 & & $F$ & 6.5 \\
\hline \multicolumn{11}{|c|}{ Chemical properties } \\
\hline \multirow{2}{*}{ pH (1:1) } & \multirow{2}{*}{$\begin{array}{c}\mathrm{EC} \\
\mathrm{dS} / \mathrm{m} \\
(1: 1)\end{array}$} & \multicolumn{4}{|c|}{ Soluble cations $(\mathrm{meq} / \mathrm{L})$} & \multicolumn{2}{|c|}{$\begin{array}{l}\text { Soluble anions } \\
(\mathrm{meq} / \mathrm{L})\end{array}$} & \multirow{2}{*}{\multicolumn{2}{|c|}{$\begin{array}{c}\text { Available } \\
\text { phosphorus } \\
\text { (ppm) }\end{array}$}} & \multirow{2}{*}{$\begin{array}{c}\text { Total } \\
\text { nitrogen } \\
(\%)\end{array}$} \\
\hline & & $\mathbf{C a}^{++}$ & S & $\mathbf{N}$ & $\mathbf{K}^{+}$ & $\begin{array}{l}\mathrm{CO}_{3}^{--}+ \\
\mathrm{HCO}_{3}^{-}\end{array}$ & $\mathrm{Cl}^{-}$ & & & \\
\hline 8.37 & 0.33 & 1.43 & 1.16 & 0.19 & 0.75 & 1.68 & 1.47 & 8.3 & & 0.0125 \\
\hline
\end{tabular}

O.M: Organic matter, S.P.: Saturation point, F.C.: Field capacity,

W.P.: Wilting point, A.W.: Available water.

\section{Experimental Design:}

The field experiment was carried in a randomized complete block design (RCBD) using a split-split plot arrangement with four replications. The nitrogen fertilizer rates $(100,120$ and $140 \mathrm{~kg} \mathrm{~N} / \mathrm{fed}$.) were assigned in the main plot, while the phosphorus fertilizer rates $(22.5$ and $30 \mathrm{~kg}$ $\mathrm{P}_{2} \mathrm{O}_{5} /$ fed.) were affected in the sub plot and potassium fertilizer rates $(24$ and $36 \mathrm{~kg} \mathrm{~K}_{2} \mathrm{O} /$ fed.) were fixed in the sub-sub plots.

The experimental unit area was $12 \mathrm{~m}^{2}(3 \times 4)$ including 4 ridges $(4 \mathrm{~m}$ length) of $60 \mathrm{~cm}$ apart at spacing 20 $\mathrm{cm}$ between hills. Nitrogen fertilizer in the from ammonium nitrate $(33.5 \%$ $\mathrm{N})$ and potassium sulphate $(48 \%$ $\mathrm{K}_{2} \mathrm{O}$ ) were divided into four equal dose: (1) The first dose was added after 10 days from sowing. (2) The second dose was added after 38 days from sowing. (3) The third dose was added after 52 days from sowing. (4) The fourth dose was added after 68 days from sowing. Moreover, calcium super phosphate $\left(15.5 \% \mathrm{P}_{2} \mathrm{O}_{5}\right)$ was applied at sowing.

Grain sorghum variety Hybrid 305 was hand sown on $13^{\text {st }}$ and $17^{\text {th }}$ June in the first and second seasons, 
respectively. After three weeks from planting, plants were thinned into two plants per hill. The preceding crop was wheat in the both season. All other agricultural practices were carried out as recommended for grain sorghum in both seasons.

\section{Characters, sampling and meas- urement:}

Data were recorded by using competitive plants from each sub-sub plot $\left(12 \mathrm{~m}^{2}\right)$. A plant was considered competitive when it was guarded from four sides, i.e. two sides on the same ridge and the other two sides on the adjacent ridges. Random samples of five plants were chosen from the four inner rows of every sub-sub plot.

The following characters were recorded:

Plant height $(\mathrm{cm})$ : measured from soil surface to the tip of the panicle, panicle length $(\mathrm{cm})$ : measured from the base to the tip of the panicle, panicle width $(\mathrm{cm})$, grain weight of panicle (gm), seed index (g) and grain yield/fed (ard.): it was estimated from the plot area in $\mathrm{kg} / \mathrm{plot}$ and converted into ardab/fed.

\section{Statistical analysis:}

The obtained data from each season were exposed to proper statistical analysis of variance according to Gomez and Gomez (1984) using the MSTAT Statistical Software package described by Co-Stat (2004). The revised least significant differences (RLSD) at 5\% level of probability were computed to detect the differences among means.

\section{Results and Discussion \\ Main effects:}

Data in Table 2 revealed that the all studied traits i.e. plant height, panicles length, width and grains weight, 1000 grain weight and grain yield/fed. were significantly affected by the nitrogen fertilizer rates in both seasons, except panicle width in the $1^{\text {st }}$ season did not significant affect by this trail. The plant height in both seasons and the panicle length, 1000 grain weight and grain yield/fed. in the second season were increased by increasing $\mathrm{N}$ fertilizer rates up to 120 $\mathrm{kg} / \mathrm{fed}$. As well as, the highest mean values of panicles width and weight in both seasons and panicle length, 1000 grain weight and grain yield/fed. in the $1^{\text {st }}$ season were recorded by $100 \mathrm{~kg} \mathrm{~N} / \mathrm{fed}$. These results mean either the medium or the lowest $\mathrm{N}$ fertilizer rate gave the highest mean values for the all studied traits. It is clear from these data that $\mathrm{N}$ fertilizer to grain sorghum enhanced the vegetative growth of the plants, increased photosynthetic activity and the metabolites required to produce wide and heavy panicles, increase grains weight and consequently produce the higher grain yield. These results coincide with mentioned by Allam et al. (2002), El-Aref et al. (2005), Buah \& Mwinkaara (2009), Afazal et al. (2012), Buah et al. (2012), Zand et al. (2014), Ayat et al. (2014) and Gebremarium \& Assefa (2015) who reported that application of N-fertilizer significantly increased plant height, panicle length, yield per panicle, 100 grain weight and grain yield over the control. As well as Sujathamma et al. (2015) came the same conclusion.

Regarding to phosphorus fertilizer rates, the results in Table 2 showed that the plant height in both seasons and panicles length and weight, 1000 grain weight and grain 
yield/fed. in the $2^{\text {nd }}$ season were affected significantly by this trail. Generally, the all studied traits increased by increasing $\mathrm{P}$ fertilizer rates in both season. These results may be due to the adding P fertilizer was useful efficiency for the crop for nutrients that giving good chance for growth. Added P fertilizer increased biomass and grain production at Arab El-Awamer soil that tested low in available $\mathrm{P}$ (8.31 ppm in Table 1). These findings are in agreement with those stated by El-Kased and Nnandy (1987), Wortmann et al. (2006), Khalili et al. (2008), Roy and Khandaker (2010) and Abou-Amer and Kewan (2014) who concluded that application of the highest rate of $\mathrm{P}$ (40 $\mathrm{kg} \mathrm{P}_{2} \mathrm{O}_{5} /$ fed.) increased grain sorghum yield.

Concerning with potassium fertilizer rates, the results in Table 2 declared that panicle length, 1000 grain weight and grain yield/fed. in the $2^{\text {nd }}$ season as well as grains weight/panicle in both seasons exerted significantly or highly significantly affected by this trail, while the plant height and panicle width in both seasons as well as panicle length, 1000 grain weight and grain yield/fed. in the first season did not significantly affected by this trail. Buah et al. (2012) reported that grain yield and yield components were not significantly affected by add $\mathrm{K}$ fertilizer. The highest mean values of grains weight/panicle (40.26 g), 1000 grain weight $(26.41 \mathrm{~g})$ and grain yield/fed. (19.47 ard.) were obtained by the highest $\mathrm{K}$ fertilizer rate in the $2^{\text {nd }}$ season, alike panicle length $(25.30$ $\mathrm{cm})$ in the $2^{\text {nd }}$ season and grains weight/panicle (35.77 g) and grain yield/fed. (17.89 ard.) in the $1^{\text {st }}$ season were obtained by the lowest $\mathrm{K}$ fertilizer rate. These results declared that either the highest or the lowest $\mathrm{K}$ fertilizer rates gave the highest values for different studied traits and consequence there are indirect same trend for this trail. Sharma \& Kumari (1996) reported that with increased K fertilizer application, sorghum grew better (taller plant) and had higher, yield. Quintero et al. (1998) observed that $\mathrm{K}$ fertilization is associated with increasing crop growth because of the positive effect of this nutrient in osmotic adjustment stomat regulation, photosynthesis and protein synthesis. Similar findings were reported by Umer (2006), Saleem et al. (2011) and Buah et al. (2012). 
Table 2. Main effect of nitrogen, phosphorus and potassium fertilizer on the plant height, yield components and yield for grain sorghum in 2014 and 2015 seasons.

\begin{tabular}{|c|c|c|c|c|c|c|c|c|c|c|c|}
\hline \multirow[t]{2}{*}{$\begin{array}{l}\text { Characters } \\
\text { Maim ef- } \\
\text { fects }\end{array}$} & \multicolumn{2}{|c|}{$\begin{array}{l}\text { Plant height } \\
\text { (cm) }\end{array}$} & \multicolumn{2}{|c|}{$\begin{array}{c}\text { Panicle } \\
\text { length }(\mathrm{cm})\end{array}$} & \multicolumn{2}{|c|}{$\begin{array}{c}\text { Panicle } \\
\text { width }(\mathrm{cm})\end{array}$} & \multicolumn{2}{|c|}{$\begin{array}{c}\text { Grains } \\
\text { weight/ } \\
\text { panicle (g) }\end{array}$} & \multicolumn{2}{|c|}{$\begin{array}{l}1000 \text { grain } \\
\text { weight (g) }\end{array}$} & \multirow{2}{*}{ 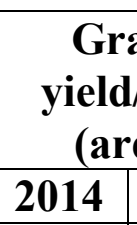 } \\
\hline & 2014 & 2015 & 2014 & 2015 & 2014 & 2015 & 2014 & 2015 & 2014 & 2015 & \\
\hline \multicolumn{12}{|l|}{$\begin{array}{l}\text { Nitrogen } \\
\text { (N) }\end{array}$} \\
\hline $\mathbf{N}_{1}$ & 142.2 & 140.9 & 26.01 & 24.98 & 6.42 & 6.86 & 39.83 & 41.07 & 24.40 & 25.63 & 19.91 \\
\hline $\mathbf{N}_{2}$ & 143.7 & 144.3 & 25.65 & 25.60 & 6.29 & 6.84 & 35.70 & 40.96 & 23.74 & 27.78 & 17.83 \\
\hline $\mathbf{N}_{3}$ & 125.3 & 138.4 & 24.56 & 23.64 & 6.38 & 5.82 & 30.30 & 36.19 & 22.79 & 23.74 & 15.18 \\
\hline F-test & $* *$ & $* *$ & $* *$ & $* *$ & N.S. & $* *$ & $* *$ & $* *$ & $* *$ & $* *$ & $* *$ \\
\hline RLSD 5\% & 1.94 & 1.86 & 0.56 & 0.52 & 0.19 & 0.23 & 0.79 & 0.49 & 0.31 & 0.53 & 0.52 \\
\hline \multicolumn{12}{|l|}{$\begin{array}{l}\text { Phosphorus } \\
\text { (P) }\end{array}$} \\
\hline $\mathbf{P}_{1}$ & 135.3 & 138.7 & 25.68 & 24.04 & 6.40 & 6.58 & 35.23 & 37.70 & 23.53 & 25.04 & 17.64 \\
\hline $\mathbf{P}_{2}$ & 138.9 & 143.8 & 25.13 & 25.43 & 6.33 & 6.43 & 35.33 & 41.11 & 23.75 & 26.39 & 17.64 \\
\hline F-test & $* *$ & $* *$ & N.S & $* *$ & N.S & N.S. & N.S. & $* *$ & N.S & $* *$ & N.S. \\
\hline \multicolumn{12}{|l|}{$\begin{array}{l}\text { Potassium } \\
\text { (K) }\end{array}$} \\
\hline $\mathbf{K}_{1}$ & 137.7 & 141.0 & 25.53 & 25.30 & 6.33 & 6.59 & 35.77 & 38.55 & 23.73 & 25.02 & 17.89 \\
\hline $\mathbf{K}_{2}$ & 136.5 & 141.4 & 25.28 & 24.18 & 6.40 & 6.43 & 34.78 & 40.26 & 23.55 & 26.41 & 17.39 \\
\hline F-test & N.S. & N.S. & N.S & $* *$ & N.S & N.S & $* *$ & $* *$ & N.S & $* *$ & N.S \\
\hline
\end{tabular}

$\mathbf{N}_{\mathbf{1}}=100 \mathrm{~kg} \mathrm{~N} /$ fed., $\mathbf{N}_{\mathbf{2}}=120 \mathrm{~kg} \mathrm{~N} /$ fed., $\mathbf{N}_{\mathbf{3}}=140 \mathrm{~kg} \mathrm{~N} /$ fed., $\mathbf{P}_{\mathbf{1}}=22.5 \mathrm{~kg} \mathbf{P}_{\mathbf{2}} \mathrm{O}_{\mathbf{5}} /$ fed., $\mathbf{P}_{\mathbf{2}}=$ $30 \mathrm{~kg} \mathrm{P}_{2} \mathrm{O}_{5} /$ fed.,

$\mathbf{K}_{\mathbf{1}}=24 \mathrm{~kg} \mathrm{~K} \mathbf{2}_{\mathbf{2}} \mathrm{O}$ fed., $\mathbf{K}_{\mathbf{2}}=36 \mathrm{~kg} \mathrm{~K}_{\mathbf{2}} \mathrm{O} /$ fed.

$*$,** indicated to significantly and highly significantly at $5 \%$ and $1 \%$ levels of probability, respectively.

N.S. $=$ Non-significant differences. RLSD $=$ Revised Least Significant Difference. 


\section{Interaction effects:}

Data in Table 3 cleared that the $\mathrm{NxP}$ (nitrogen $\mathrm{x}$ phosphorus) interaction had a highly significantly effect on the all studied traits, except grains weight/panicle and grain yield/fed. in the $1^{\text {st }}$ season as well as panicle width in the $2^{\text {nd }}$ season. The tallest plant $(148.3 \mathrm{~cm})$, maximum grain yield/fed. (20.25 ard.) in the $1^{\text {st }}$ season, tallest panicle $(26.23 \mathrm{~cm})$ in the $2^{\text {nd }}$ season, the heaviest panicle grains $(40.50$ and $44.11 \mathrm{~g})$ and heaviest 1000 grain (25.60 and 28.63 g) in both season were obtained by $\mathrm{N}_{1} \times \mathrm{P}_{2}$ (100 kg N x $30 \mathrm{~kg} \mathrm{P}_{2} \mathrm{O}_{5} /$ fed.) interaction treatment. Bauh et al. (2012) declared that NxP interaction did not show significant influence for any parameters. Here too, the tallest panicle $(27.08 \mathrm{~cm})$ and the widest panicle $(6.60 \mathrm{~cm})$ in the $1^{\text {st }}$ season were recorded by $\mathrm{N}_{1} \mathrm{xP}_{1}(100$ $\mathrm{kg} \mathrm{N}$ x $22.5 \mathrm{~kg} \mathrm{P}_{2} \mathrm{O}_{5} /$ fed.) interaction treatments. As well as the tallest plant $(146.3 \mathrm{~cm})$ and the maximum grain yield/fed. (21.60 ard.) in the $2^{\text {nd }}$ season were detected by $\mathrm{N}_{2} \mathrm{XP}_{1}(120$ $\mathrm{kg} \mathrm{N} \times 22.5 \mathrm{~kg} \mathrm{P}_{2} \mathrm{O}_{5} /$ fed.) and $\mathrm{N}_{2} \mathrm{XP}_{2}$ (120 kg N x 30 kg $\mathrm{P}_{2} \mathrm{O}_{5} /$ fed.) interaction treatments, respectively. On the other hand, in general, either $\mathrm{N}_{3} \times \mathrm{P}_{1}$ (140 kg N x $22.5 \mathrm{~kg} \mathrm{P}_{2} \mathrm{O}_{5} /$ fed.) or $\mathrm{N}_{3} \times \mathrm{P}_{2}\left(140 \mathrm{~kg} \mathrm{~N}\right.$ x $30 \mathrm{~kg} \mathrm{P}_{2} \mathrm{O}_{5} /$ fed.) interaction treatment gave the lowest values for all the studied traits. These results are in conformity with those obtained by Ashiono et al. (2005) who reported that application of 40 $\mathrm{kg} \mathrm{N} / \mathrm{ha}$ and $20 \mathrm{~kg} \mathrm{P} /$ ha produced the highest grain yield (9.85 tons/ha), However, the tallest plant $(162 \mathrm{~cm})$ was at $40 \mathrm{~kg} \mathrm{~N} / \mathrm{ha}$ and either $30 \mathrm{~kg} \mathrm{P}$ or $90 \mathrm{~kg} \mathrm{P} / \mathrm{ha}$, as well as, the greatest 100 kernel weight $(2.3 \mathrm{~g})$ was at 40 $\mathrm{kg} \mathrm{N} /$ ha with $50 \mathrm{~kg} \mathrm{P} / \mathrm{ha}$.

With attention to the NxK (nitrogen $\mathrm{x}$ potassium) interaction, the results in Table 4 revealed that the all studied traits exerted highly significantly influenced by this interaction, except plant height in the $1^{\text {st }}$ season and panicle length in the $2^{\text {nd }}$ season did not show any significant. The $\mathrm{N}_{1} \mathrm{xK}_{1} \quad\left(\begin{array}{llllll}100 & \mathrm{~kg} & \mathrm{~N} & \mathrm{x} & 24 & \mathrm{~kg}\end{array}\right.$ $\mathrm{K}_{2} \mathrm{O} /$ fed.) interaction treatment realized the highest values for panicle length $(26.85 \mathrm{~cm})$, panicle width $(6.64 \mathrm{~cm})$, grains weight/panicle (41.08 g) and grain yield/fed. (20.54 ard.) in the $1^{\text {st }}$ season. 
Table 3. Interaction effect of nitrogen $x$ phosphorus fertilizer $(\mathrm{NxP})$ on the plant height, yield components and yield for grain sorghum in 2014 and 2015 seasons.

\begin{tabular}{|c|c|c|c|c|c|c|c|c|c|c|c|c|}
\hline \multirow{2}{*}{\multicolumn{2}{|c|}{$\begin{array}{l}\text { Characters } \\
N \times\end{array}$}} & \multicolumn{2}{|c|}{$\begin{array}{l}\text { Plant height } \\
\text { (cm) }\end{array}$} & \multicolumn{2}{|c|}{$\begin{array}{c}\text { Panicle } \\
\text { length }(\mathrm{cm})\end{array}$} & \multicolumn{2}{|c|}{$\begin{array}{c}\text { Panicle } \\
\text { width }(\mathrm{cm})\end{array}$} & \multicolumn{2}{|c|}{$\begin{array}{c}\text { Grains } \\
\text { weight/ } \\
\text { panicle }(g)\end{array}$} & \multicolumn{2}{|c|}{$\begin{array}{l}1000 \text { grain } \\
\text { weight (g) }\end{array}$} & \multirow{2}{*}{\begin{tabular}{c|}
$\begin{array}{c}\text { Gra } \\
\text { yield }\end{array}$ \\
2014 \\
\end{tabular}} \\
\hline & & 14 & 15 & 14 & 15 & 4 & 015 & 2014 & 2015 & 4 & 2015 & \\
\hline \multirow{2}{*}{$\mathbf{N}_{1}$} & $\mathbf{P}_{1}$ & & & & & & & 39.15 & 3 & 0 & 3 & 58 \\
\hline & $\mathbf{P}_{2}$ & 18.3 & 14 & & & & & 40.50 & 44.11 & 25.60 & 8.63 & .25 \\
\hline \multirow{2}{*}{$\mathbf{N}_{2}$} & $\mathbf{P}_{1}$ & & & & & & & 0 & 38.75 & & & \\
\hline & $\mathbf{P}_{2}$ & & & & & & & 5.40 & 18 & & & 1.64 \\
\hline \multirow{2}{*}{$N_{3}$} & $\mathbf{P}_{1}$ & & & & & & & 3 & 36.33 & & & 15.32 \\
\hline & $\mathbf{P}_{2}$ & 124.2 & 145.3 & J & 24.45 & & & 30.08 & 36.05 & 22.23 & 22.43 & 15.04 \\
\hline & $* *$ & 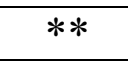 & 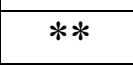 & ** & 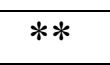 & & S. & ** & ** & ** & N.S \\
\hline \multicolumn{2}{|c|}{ RLSD 5\% } & 2.6 & 0.88 & 0.89 & 0.36 & 0.19 & 0.41 & 1.42 & 0.53 & 0.68 & 0.70 & 1.28 \\
\hline
\end{tabular}

$\mathbf{N}_{\mathbf{1}}=100 \mathrm{~kg} \mathrm{~N} /$ fed., $\mathbf{N}_{\mathbf{2}}=120 \mathrm{~kg} \mathrm{~N} /$ fed., $\mathbf{N}_{\mathbf{3}}=140 \mathrm{~kg} \mathrm{~N} /$ fed., $\mathbf{P}_{\mathbf{1}}=22.5 \mathrm{~kg} \mathbf{P}_{\mathbf{2}} \mathrm{O}_{\mathbf{5}} /$ fed., $\mathbf{P}_{\mathbf{2}}$ $=30 \mathrm{~kg} \mathrm{P} \mathrm{O}_{5} /$ fed.,

$\mathbf{K}_{\mathbf{1}}=24 \mathrm{~kg} \mathrm{~K}_{\mathbf{2}} \mathrm{O} /$ fed., $\mathbf{K}_{\mathbf{2}}=36 \mathrm{~kg} \mathrm{~K}_{\mathbf{2}} \mathrm{O} /$ fed.

*,** indicated to significantly and highly significantly at 5\% and $1 \%$ levels of probability, respectively.

N.S. $=$ Non-significant differences. RLSD $=$ Revised Least Significant Difference. 
Table 4. Interaction effect of nitrogen $x$ potassium fertilizers $(\mathrm{NxK})$ and phosphorus $x$ potassium fertilizer (PxK) on the plant height, yield components and yield for grain sorghum in 2014 and 2015 seasons.

\begin{tabular}{|c|c|c|c|c|c|c|c|c|c|c|c|c|}
\hline \multirow{2}{*}{\multicolumn{2}{|c|}{$\begin{array}{r}\text { Charac- } \\
\text { ters }\end{array}$}} & \multicolumn{2}{|c|}{$\begin{array}{l}\text { Plant height } \\
\text { (cm) }\end{array}$} & \multicolumn{2}{|c|}{$\begin{array}{c}\text { Panicle } \\
\text { length }(\mathrm{cm})\end{array}$} & \multicolumn{2}{|c|}{$\begin{array}{c}\text { Panicle } \\
\text { width }(\mathrm{cm})\end{array}$} & \multicolumn{2}{|c|}{$\begin{array}{c}\text { Grains } \\
\text { weight/ } \\
\text { panicle (g) }\end{array}$} & \multicolumn{2}{|c|}{$\begin{array}{l}1000 \text { grain } \\
\text { weight }(g)\end{array}$} & \multirow{2}{*}{\begin{tabular}{|r|}
$\begin{array}{r}\text { Gra } \\
\text { yield/ }\end{array}$ \\
2014 \\
\end{tabular}} \\
\hline & & 2014 & 2015 & 2014 & 2015 & 2014 & 2015 & 2014 & 2015 & 2014 & 2015 & \\
\hline \multirow{2}{*}{$N_{1}$} & $K_{1}$ & 142.2 & 137.3 & 26.85 & 25.50 & 6.64 & 6.60 & 41.08 & 38.04 & 23.70 & 22.88 & 20.54 \\
\hline & $\mathbf{K}_{2}$ & 142.3 & 144.5 & 25.18 & 24.45 & 6.21 & 7.13 & 38.58 & 44.10 & 25.10 & 28.38 & 19.29 \\
\hline \multirow[b]{2}{*}{$\mathbf{N}_{2}$} & $K_{1}$ & 143.7 & 150.6 & 25.23 & 26.15 & 6.21 & 7.23 & 34.48 & 42.45 & 23.53 & 27.44 & 17.20 \\
\hline & $\mathbf{K}_{2}$ & 143.7 & 138.0 & 26.08 & 25.05 & 6.38 & 6.45 & 36.93 & 39.48 & 23.95 & 28.13 & 18.45 \\
\hline \multirow[b]{2}{*}{$\mathbf{N}_{3}$} & $\mathbf{K}_{1}$ & 127.3 & 135.1 & 24.53 & 24.25 & 6.14 & 5.94 & 31.76 & 35.18 & 23.98 & 24.75 & 15.94 \\
\hline & $\mathbf{K}_{2}$ & 123.4 & 141.8 & 24.60 & 23.03 & 6.61 & 5.70 & 28.84 & 37.20 & 21.60 & 22.74 & 14.42 \\
\hline \multicolumn{2}{|c|}{ F-test } & N.S & $* *$ & $* *$ & N.S & $* *$ & $* *$ & $* *$ & $* *$ & $* *$ & $* *$ & $* *$ \\
\hline \multicolumn{2}{|c|}{ RLSD 5\% } & 3.10 & 0.80 & 1.03 & - & 0.20 & 0.27 & 0.70 & 0.66 & 0.52 & 0.57 & 0.87 \\
\hline \multicolumn{13}{|l|}{$\begin{array}{c}\mathbf{P} \mathbf{x} \\
\mathbf{K}\end{array}$} \\
\hline \multirow{2}{*}{$\mathbf{P}_{1}$} & $\mathbf{K}_{1}$ & 138.1 & 136.3 & 26.62 & 24.40 & 6.45 & 6.72 & 36.64 & 35.30 & 23.40 & 23.67 & 18.38 \\
\hline & $\mathbf{K}_{2}$ & 132.5 & 141.0 & 24.75 & 23.68 & 6.34 & 6.45 & 33.81 & 40.10 & 23.67 & 26.42 & 16.90 \\
\hline \multirow{2}{*}{$\mathbf{P}_{2}$} & $\mathbf{K}_{1}$ & 137.3 & 145.7 & 24.45 & 26.20 & 6.21 & 6.46 & 34.90 & 41.81 & 24.07 & 26.38 & 17.41 \\
\hline & $\mathbf{K}_{2}$ & 140.5 & 141.8 & 25.82 & 24.67 & 6.46 & 6.40 & 35.75 & 40.42 & 23.43 & 26.41 & 17.88 \\
\hline \multicolumn{2}{|c|}{ F-test } & ** & ** & ** & ** & ** & N.S. & ** & ** & * & ** & ** \\
\hline \multicolumn{2}{|c|}{ RLSD 5\% } & 2.17 & 0.66 & 0.75 & 0.36 & 0.17 & 0.30 & 0.57 & 0.54 & 0.48 & 0.47 & 0.71 \\
\hline
\end{tabular}

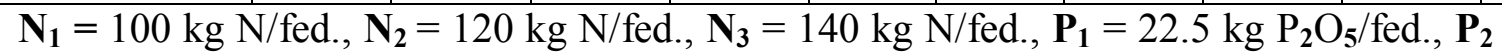
$=30 \mathrm{~kg} \mathrm{P} \mathrm{O}_{5} /$ fed.,

$\mathbf{K}_{\mathbf{1}}=24 \mathrm{~kg} \mathrm{~K} \mathbf{2} /$ fed., $\mathbf{K}_{\mathbf{2}}=36 \mathrm{~kg} \mathrm{~K} \mathbf{2}_{2} \mathrm{O}$ fed.

*, ** indicated to significantly and highly significantly at $5 \%$ and $1 \%$ levels of probability, respectively.

N.S. $=$ Non-significant differences. RLSD $=$ Revised Least Significant Difference. 
As well as, the $\mathrm{N}_{1} \mathrm{xK}_{2}(100 \mathrm{~kg} \mathrm{~N} \times 36$ $\mathrm{kg} \mathrm{K}_{2} \mathrm{O}$ /fed.) interaction realized the highest mean values of grains weight/panicle $(44.10 \mathrm{~g})$ and 1000 grain weight (25.10 and 28.38) in the $1^{\text {st }}$ and $2^{\text {nd }}$ seasons, respectively. Moreover, the $\mathrm{N}_{2} \mathrm{xK}_{1}$ interaction gave the highest mean values of plant height $(150.6 \mathrm{~cm})$, panicle length $(26.15 \mathrm{~cm})$, panicle width $(7.23 \mathrm{~cm})$ and maximum grain yield (21.24 ard.) in the $2^{\text {nd }}$ season. On the contrary, overall either $\mathrm{N}_{3} \mathrm{xK}_{1}$ or $\mathrm{N}_{3} \mathrm{xK}_{2}(120$ $\mathrm{kg} \mathrm{N}$ x $24 \mathrm{~kg} \mathrm{~K} 2 \mathrm{O} /$ fed.) or (120 kg N x $36 \mathrm{~kg} \mathrm{~K} \mathrm{~K}_{2} \mathrm{O} / \mathrm{fed}$.) interaction treatment recorded the lowest values for all the studied traits. Buah et al. (2012) mentioned that any parameter had not significantly affected by NxK interaction treatments.

As far the PxK (phosphorus $\mathrm{x}$ potassium) interaction, data in Table 4 indicated that the all studied traits were affected significantly by this interaction in both seasons, except panicle width in the $2^{\text {nd }}$ season. The $\mathrm{P}_{1} \times K_{1}\left(22.5 \mathrm{P}_{2} \mathrm{O}_{5}\right.$ x $24 \mathrm{~kg} \mathrm{~K} 2 \mathrm{O} /$ fed.) interaction treatment pointed out the highest values for panicle length $(26.26 \mathrm{~cm})$, grain weight/panicle $(36.64 \mathrm{~g})$ and grain yield/fed. (18.38 ard.) in the $1^{\text {st }}$ season. As well as, $\mathrm{P}_{2} \mathrm{xK}_{1}\left(30 \mathrm{~kg} \mathrm{P}_{2} \mathrm{O}_{5}\right.$ x $24 \mathrm{~kg} \mathrm{~K} 2 \mathrm{O} /$ fed.) interaction treatment confirmed the highest values for plant height (145.7 $\mathrm{cm})$, panicle length $(26.20 \mathrm{~cm})$, grain weight/panicle $(41.81 \mathrm{~g})$ and grain yield/fed. $(20.43$ ard. $)$ in the $2^{\text {nd }}$ season, whereas the heaviest 1000 grain $(24.07 \mathrm{~g})$ was found in the $1^{\text {st }}$ season. Moreover, the $\mathrm{P}_{2} \mathrm{xK}_{2}$ interaction treatment decided the tallest plant $(140.5 \mathrm{~cm})$ and tallest panicle $(6.46$ $\mathrm{cm})$ in the $1^{\text {st }}$ season. On other hand, in general, either $\mathrm{P}_{1} \times \mathrm{XK}_{1}$ or $\mathrm{P}_{1} \mathrm{xK}_{2}$ $\left(22.5 \mathrm{P}_{2} \mathrm{O}_{5} \times 24 \mathrm{~kg} \mathrm{~K} 2 \mathrm{O} /\right.$ fed.) or $(22.5$ $\mathrm{P}_{2} \mathrm{O}_{5} \times 36 \mathrm{~kg} \mathrm{~K} 2 \mathrm{O} /$ fed.) interaction treatment illustrated the lowest values for all studied traits. Buah et al. (2012) noted that PxK interaction was not significant for any studied parameters.

With respect to the second order interaction (nitrogen $\mathrm{x}$ phosphorus $\mathrm{x}$ potassium), data in Table 5 reported that the all studied traits exerted significantly or highly significantly influenced by the second order interaction, except panicle width in both seasons. The tallest plants (150.1 and $154.8 \mathrm{~cm})$ were recorded by $\mathrm{N}_{1} \mathrm{XP}_{2} \mathrm{xK}_{1}$ and $\mathrm{N}_{2} \mathrm{xP}_{2} \mathrm{xK}_{1}(100 \mathrm{~kg} \mathrm{~N} \mathrm{x}$ $30 \mathrm{~kg} \mathrm{P}_{2} \mathrm{O}_{5} \times 24 \mathrm{~kg} \mathrm{~K} 2 \mathrm{O} /$ fed.) and $\left(120 \mathrm{~kg} \mathrm{~N} \times 30 \mathrm{~kg} \mathrm{P}_{2} \mathrm{O}_{5} \times 24 \mathrm{~kg}\right.$ $\mathrm{K}_{2} \mathrm{O}$ /fed.) interaction treatments; the tallest panicles $(28.45 \mathrm{~cm}$ and 27.25 $\mathrm{cm})$ were obtained by $\mathrm{N}_{1} \mathrm{xP}_{1} \mathrm{xK}_{1}$ and $\mathrm{N}_{1} \mathrm{XP}_{2} \mathrm{xK}_{1}\left(100 \mathrm{~kg} \mathrm{~N}\right.$ x $22.5 \mathrm{~kg} \mathrm{P}_{2} \mathrm{O}_{5} \mathrm{x}$ $24 \mathrm{~kg} \mathrm{~K}_{2} \mathrm{O} /$ fed.) and $(100 \mathrm{~kg} \mathrm{~N} \mathrm{x} 30$ $\mathrm{kg} \mathrm{P}_{2} \mathrm{O}_{5} \times 24 \mathrm{~kg} \mathrm{~K}_{2} \mathrm{O} /$ fed.) interaction treatments; the heaviest grains/panicle (42.93 and $44.75 \mathrm{~g}$ ) were detected by $\mathrm{N}_{1} \mathrm{xP}_{2} \mathrm{xK}_{1}$ and $\mathrm{N}_{1} \mathrm{XP}_{2} \mathrm{xK}_{2}\left(100 \mathrm{~kg} \mathrm{~N}\right.$ x $30 \mathrm{~kg} \mathrm{P}_{2} \mathrm{O}_{5} \mathrm{x}$ $24 \mathrm{~kg} \mathrm{~K}_{2} \mathrm{O} /$ fed.) and $(100 \mathrm{~kg} \mathrm{~N} \mathrm{x} 30$ $\mathrm{kg} \mathrm{P}_{2} \mathrm{O}_{5} \times 36 \mathrm{~kg} \mathrm{~K}_{2} \mathrm{O} /$ fed.) interaction treatments; the heaviest 1000 grain (26.00 and $29.38 \mathrm{~g}$ ) were observed at $\mathrm{N}_{1} \mathrm{XP}_{2} \mathrm{xK}_{2}\left(100 \mathrm{~kg} \mathrm{~N} \times 30 \mathrm{~kg} \mathrm{P}_{2} \mathrm{O}_{5} \mathrm{x}\right.$ $36 \mathrm{~kg} \mathrm{~K} \mathrm{~K}_{2} \mathrm{O} /$ fed.) and the maximum grain yield/fed. (21.46 and 22.78 ard.) were recorded by $\mathrm{N}_{1} \mathrm{xP}_{2} \mathrm{xK}_{1}$ and $\mathrm{N}_{2} \mathrm{XP}_{2} \mathrm{xK}_{1}\left(100 \mathrm{~kg} \mathrm{~N}\right.$ x $30 \mathrm{~kg} \mathrm{P}_{2} \mathrm{O}_{5} \mathrm{x}$ $24 \mathrm{~kg} \mathrm{~K}_{2} \mathrm{O} /$ fed.) and (120 kg N x 30 $\mathrm{kg} \mathrm{P}_{2} \mathrm{O}_{5} \times 24 \mathrm{~kg} \mathrm{~K}_{2} \mathrm{O} /$ fed.) interaction treatments in the $1^{\text {st }}$ and $2^{\text {nd }}$ seasons, respectively. On the contrary, overall, $\mathrm{N}_{3}$ with $\mathrm{P}_{1}$ or $\mathrm{P}_{2}$ and with $\mathrm{K}_{1}$ or $\mathrm{K}_{2}$ recorded the lowest values for all traits in this study. Buah et al. (2012) reported that NxPxK interaction was not significant for 1000 kernel weight and grain yield. 
Table 5. Effect of the second order interaction (NxPxK) on the plant height, yield components and yield for grain sorghum in 2014 and 2015 seasons.

\begin{tabular}{|c|c|c|c|c|c|c|c|c|c|c|c|c|c|}
\hline \multirow{3}{*}{\multicolumn{2}{|c|}{ Characters }} & \multicolumn{4}{|c|}{ Plant height (cm) } & \multicolumn{4}{|c|}{ Panicle length (cm) } & \multicolumn{4}{|c|}{ Panicle width $(\mathrm{cm})$} \\
\hline & & \multicolumn{2}{|c|}{2014} & \multicolumn{2}{|c|}{2015} & \multicolumn{2}{|c|}{2014} & \multicolumn{2}{|c|}{2015} & \multicolumn{2}{|c|}{2014} & \multicolumn{2}{|c|}{2015} \\
\hline & & $K_{1}$ & $\mathbf{K}_{2}$ & $\mathbf{K}_{1}$ & $\mathbf{K}_{2}$ & $K_{1}$ & $\mathbf{K}_{2}$ & $K_{1}$ & $\mathbf{K}_{2}$ & $\mathbf{K}_{1}$ & $\mathbf{K}_{2}$ & $K_{1}$ & $\mathbf{K}_{2}$ \\
\hline \multirow{2}{*}{$\mathbf{N}_{1}$} & $\mathbf{P}_{1}$ & 134.2 & 138.7 & 135.5 & 140.8 & 28.45 & 25.70 & 23.75 & 23.70 & 6.85 & 6.35 & 6.50 & 6.98 \\
\hline & $\mathbf{P}_{2}$ & 150.1 & 146.6 & 139.0 & 148.3 & 25.25 & 24.65 & 27.25 & 25.20 & 6.43 & 6.08 & 6.70 & 7.28 \\
\hline \multirow{2}{*}{$\mathbf{N}_{2}$} & $\mathbf{P}_{1}$ & 145.5 & 140.9 & 146.5 & 146.0 & 25.40 & 25.30 & 25.80 & 25.35 & 6.13 & 6.23 & 7.53 & 6.58 \\
\hline & $\mathbf{P}_{2}$ & 142.0 & 146.5 & 154.8 & 130.0 & 25.05 & 26.85 & 26.50 & 24.75 & 6.30 & 6.53 & 6.92 & 6.33 \\
\hline \multirow{2}{*}{$\mathbf{N}_{3}$} & $\mathbf{P}_{1}$ & 134.7 & 118.4 & 127.0 & 136.3 & 26.00 & 23.25 & 23.65 & 22.00 & 6.38 & 6.45 & 6.13 & 5.80 \\
\hline & $\mathbf{P}_{2}$ & 119.9 & 128.5 & 43.3 & 147.3 & 23.05 & 25.95 & 24.85 & 24.05 & 5.90 & 6.78 & 5.75 & 5.60 \\
\hline \multicolumn{2}{|c|}{ F-test } & \multicolumn{2}{|c|}{$* *$} & \multicolumn{2}{|c|}{$* *$} & & \multicolumn{2}{|c|}{$1-$} & \multicolumn{2}{|c|}{ N.S } & \multicolumn{2}{|c|}{ N.S } \\
\hline \multirow{2}{*}{\multicolumn{2}{|c|}{$\begin{array}{l}\text { RLSD 5\% } \\
\text { Characters }\end{array}$}} & \multicolumn{2}{|c|}{3.67} & \multicolumn{2}{|c|}{1.36} & \multicolumn{2}{|c|}{1.51} & \multicolumn{2}{|c|}{0.63} & \multicolumn{2}{|c|}{0.32} & \\
\hline \multirow{3}{*}{\multicolumn{2}{|c|}{$\begin{array}{l}\text { Characters } \\
\text { NxPxK }\end{array}$}} & \multicolumn{4}{|c|}{$\begin{array}{c}\text { Grains weight/panicle } \\
\text { (g) }\end{array}$} & \multicolumn{4}{|c|}{1000 grain weight (g) } & \multicolumn{4}{|c|}{ Grain yield/fed. } \\
\hline & & 20 & 14 & 20 & & & & & 15 & & & & \\
\hline & & $\mathbf{K}_{1}$ & $\mathbf{K}_{2}$ & $\mathbf{K}_{1}$ & $\mathbf{K}_{2}$ & $\mathbf{K}_{1}$ & $\mathbf{K}_{2}$ & $K_{1}$ & $\mathbf{K}_{2}$ & $K_{1}$ & $\mathbf{K}_{2}$ & $K_{1}$ & $\mathbf{K}_{2}$ \\
\hline & $\mathbf{P}_{1}$ & 39.23 & 39.08 & 32.60 & 43.45 & 22.20 & 24.20 & 17.88 & 27.38 & 19.61 & 19.54 & 16.30 & 21.73 \\
\hline $\mathbf{N}_{1}$ & $\mathbf{P}_{2}$ & 42.93 & 38.08 & 43.48 & 44.75 & 25.20 & 26.00 & 27.88 & 29.38 & 21.46 & 19.04 & 19.99 & 18.43 \\
\hline & $\mathbf{P}_{1}$ & 35.46 & 36.55 & 39.40 & 38.10 & 24.00 & 24.10 & 26.63 & 28.25 & 17.78 & 18.26 & 19.70 & 19.05 \\
\hline $\mathbf{N}_{2}$ & $\mathbf{P}_{2}$ & 33.50 & 37.30 & 34.50 & 40.85 & 23.05 & 23.80 & 28.25 & 28.00 & 16.63 & 18.65 & 22.78 & 20.43 \\
\hline & $\mathbf{P}_{1}$ & 35.25 & 25.80 & 33.90 & 38.75 & 24.00 & 22.70 & 26.50 & 23.63 & 17.74 & 12.91 & 16.70 & 19.38 \\
\hline & $\mathbf{P}_{2}$ & 28.28 & 31.88 & 36.45 & 35.65 & 23.95 & 20.50 & 23.00 & 21.85 & 14.14 & 15.94 & 18.25 & 17.83 \\
\hline & & & & - & & & & & $*$ & & 1 & & \\
\hline RLS & $\%$ & 0 . & & 0. & & & 83 & 0 . & 81 & & & & \\
\hline
\end{tabular}

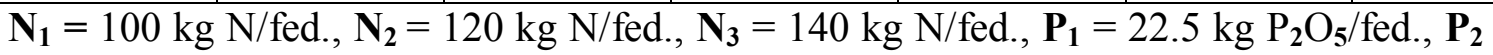

$=30 \mathrm{~kg} \mathrm{P}_{2} \mathrm{O}_{5} / \mathrm{fed}$.,

$\mathbf{K}_{\mathbf{1}}=24 \mathrm{~kg} \mathrm{~K} \mathbf{O}_{2} \mathrm{O}$ fed., $\mathbf{K}_{\mathbf{2}}=36 \mathrm{~kg} \mathrm{~K} \mathrm{O}_{2} \mathrm{O}$ fed.

$*$, ** indicated to significantly and highly significantly at $5 \%$ and $1 \%$ levels of probability, respectively.

N.S. $=$ Non-significant differences. RLSD $=$ Revised Least Significant Difference. 


\section{References}

Abou-Amer, A.I. and K.Z. Kewan (2014). Effect of NP fertilization levels on sorghum (Sorghum bicolor L.) yield and fodder quality for Animals. Alex. J. Agric. Res., 59 (1): 51-59.

Afzal, M.; A. Ahmadi and H. Ahmadi (2012). Effect of nitrogen on growth and yield of sorghum forage (Sorghum bicolor (L.) Moench cv.) under three cutting system. Cercetari Agronomice in Moldova., 4 (152): 57-64.

Akram, A.; M. Fatima; S. Ali; G. Jilani and R. Asghar (2007). Growth, yield and nutrients uptake of sorghum in response to integration phosphorus and potassium management. Pak. J. Bot., 39 (4): 1083-1087.

Allam, A.Y.; G.R. El-Nagar; M.M. AbdAlla and N. Ibrahim (2002). Response of some grain sorghum cultivars to planting density and nitrogen fertilization. Assiut J. Agric. Sci., 33 (2): 133-150.

Ashiono, G.B.; S. Gotuiku; P. Mwangi and I.E. Akuja (2005). Effect of nitrogen and phosphorus application on growth and yield of dualpurpose sorghum (Sorghum bicolor (L.) Moench), E1291, in the dry highlands of Kenya. Asian J. Plant Sci., 4: 379-382.

Ayat, B.H.; E.M.M. Shalaby; A.Y. Allam; E.A. Ali and M.T. Said (2014). Effect of NPK fertilization and splitting on the grain yield and its components of two sorghum cultivars. Assiut J. Agric. Sci., 45 (4): 1-14.

Buah, S.S.J. and S. Mwinkaara (2009). Response of sorghum to nitrogen fertilizer and plant density in the Guinea Savanna zone. J. Agron., 8: 124-130.

Buah, S.S.J.; J.M. Kombiok and L.N. Abatania (2012). Grain sorghum response to NPK fertilizer in the Guinea Savanna of Ghana. J. of Crop Improvement, 26: 101-115.

Costat Statistical Software (2004). CoStat Manual Revision, 4 (2) 271.

El-Aref, Kh.A.O.; S.E. Abdel-Mawly and A.S. Abo-Elhamd (2005). Improving yield and water use efficiency of two sorghum cultivars irrigated by surface and drip irrigation systems and fertilized by nitrogen. Ass. Unv. Bull. Environ. Res. 8 (2): 67-80.

El-Kased, F.A. and L.A. Nnady (1982). Phosphorus response of grain sorghum in the Guinea savanna of Nigeria as influenced by rates, placement and plant spacing. Fert. Res., (11): 3-8.

Gebremariam, G. and D. Assefa (2015). Nitrogen fertilization effect on grain sorghum (Sorghum bicolor L., Moench) yield, yield components and witchweed (Striga hermonthica (Del.) Benth) infestation in northern Ethiopia. Int. J. Agric. Res., 1-10.

Gomez, K.A. and A.A. Gomez (1984). Statistical Procedures for Agricultural Research. $2^{\text {nd }}$ ed., Wiley, New York.

Kayuki, C.K.; J. Byalebeka; C.S. Wortmann and M. Mamo (2007). Low input approaches for soil fertility management in semiarid eastern Uganda. Agron. J., (99): 847-853.

Khalili, A.; N. Akbari and M.R. Chachi (2008). Limited irrigation and phosphorus fertilizer effects on yield and yield components of grain sorghum (Sorghum bicolor L. var Kimia). American-Eurasian J. Agric. \& Environ. Sci., 3 (5): 697-702.

Miko, S. and A.A. Manga (2008). Effect of intra-spacing and nitrogen rates on growth and yield of sorghum 
(Sorghum bicolor L.) var. ICSV 400. Pat 4 (2): 66-73.

Quintero, J.M.; J.M. Fournier; J.M. Ramos and M. Benlloch (1998). $\mathrm{K}+$ status and ABA affect both exudation rate and hydraulic conductivity in sunflower roots. Physi. Planta. (102): 279-284.

Roy, P.R.S. and Z.H. Khandaker (2010). Effect of phosphorus fertilizer on yield and nutritional value of sorghum (Sorghum bicolor) fodder of three cuttings. Bang. J. Anim. Sci., $39(1 / 2)$ : 106-115.

Saleem, A.; H.I. Javed; R. Saleem; M. Ansar and M.A. Zia (2011). Effect of split application of potash fertilizer on maize and sorghum. Pakistan J. Agric. Res., 24 (1/4): 31-34.

Sharma, P.S. and T.S. Kumari (1996). Effect of potassium under water stress on growth and yield of sorghum in Vertisol. J. Potash. Res., 12 (3): 319-325.

Shrotriya, G.G. (1998). Balanced fertilization - Indian experience. Proc. Symp. Plant Nutrition Management in Vetrisol. J. Potash. Res., 12 (3): 319-325.
Sujathamma, P.; K. Kavitha and V. Suneetha (2015). Response of grain sorghum (Sorghum bicolor L.) cultivars to different fertilizer levels under rainfed condition. Int. J. Agric. Sci., 5 (1): 381-385.

Umer, S. (2006). Alleviating adverse effect of water stress on yield of sorghum, mustared and groundnut by potassium application. Pakistan J. Bot., 38 (5): 1373-1380.

Varvel, G.E. and W.W. Wilhelm (2003). Soybean nitrogen contribution to corn and sorghum in Western Corn Belt rotations. Agron. J., 95 (1): 220-221.

Wortmann, C.S.; S.A. Xerinda and M. Mamo (2006). No-till row crop response to starter fertilizer in eastern Nebraska: II- Rainfed grain sorghum. Agron. J. (98): 187-193.

Zand, N.; M.R. Shakiba; M.M. Vahed and A.D.M. Nasab (2014). Response of sorghum to nitrogen fertilizer at different plant densities. Int. J. of Farming and Allied Sci., 3 (1): 71-74. 
تأثير التسميد بالنيتروجين والفوسفور والبوتاسيوم في الأراضي حديثة الإستصلاح علي إنتاجية الذرة

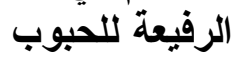

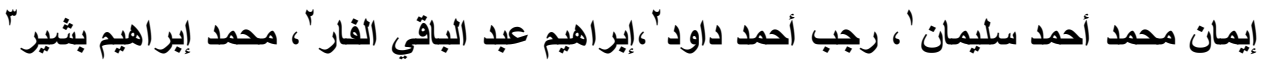

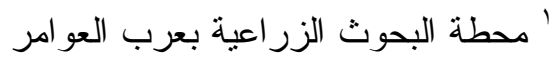

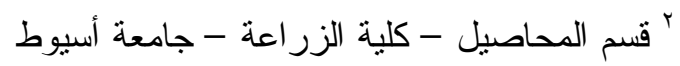

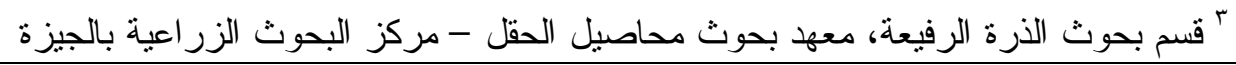

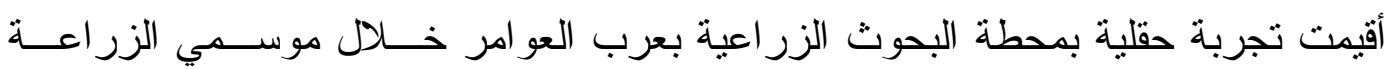

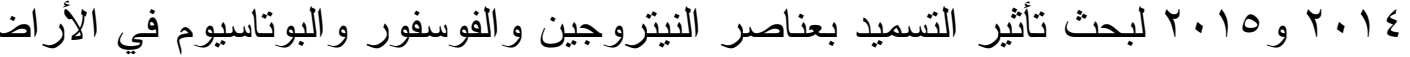

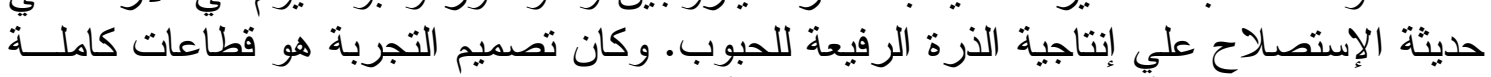

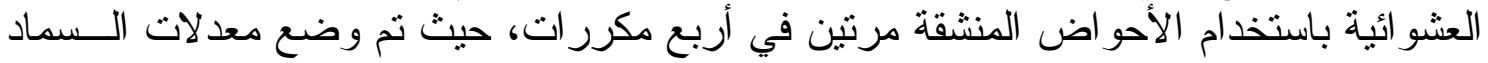

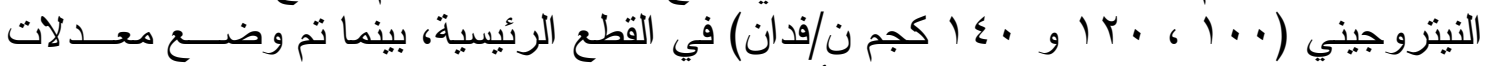

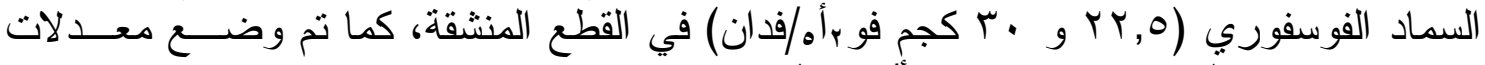

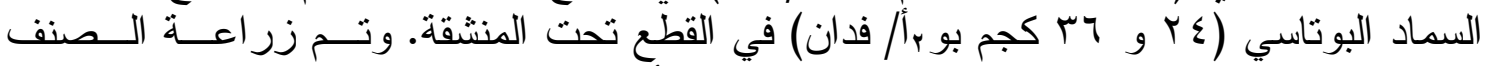

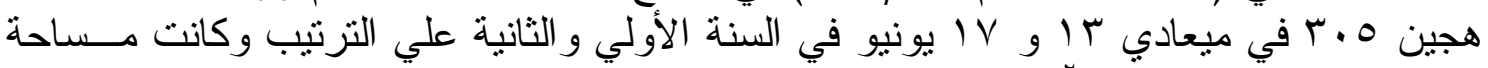

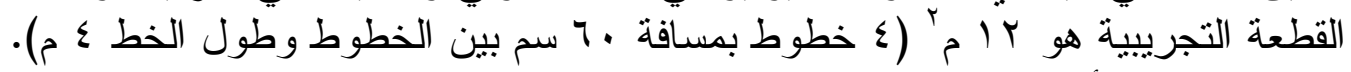

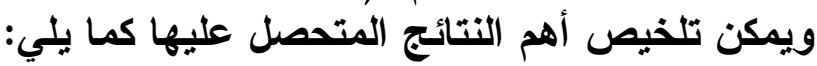

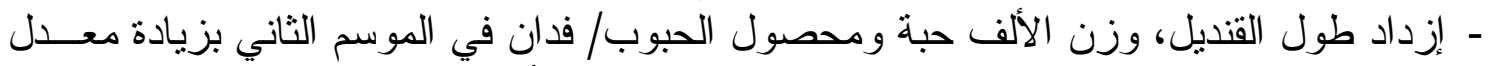

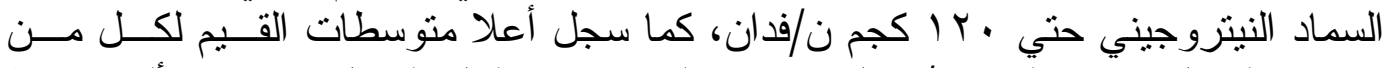

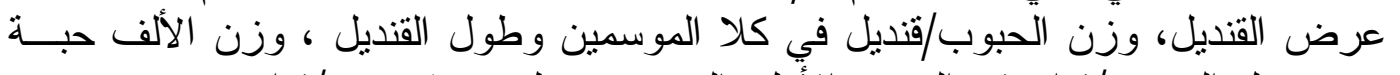

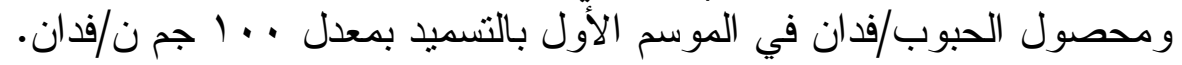

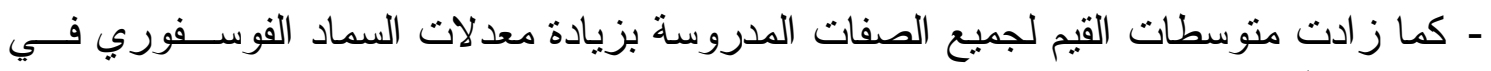
كلا الموسمين.

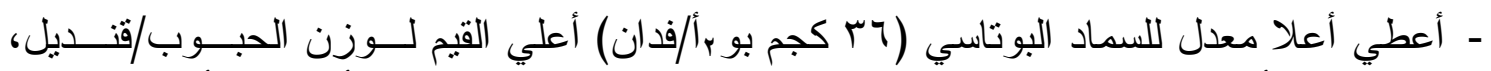

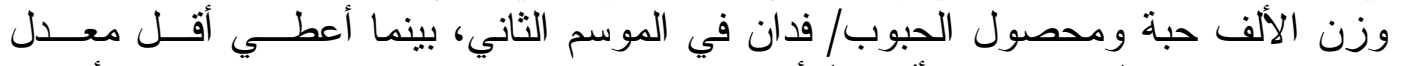

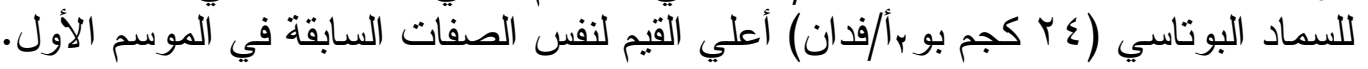

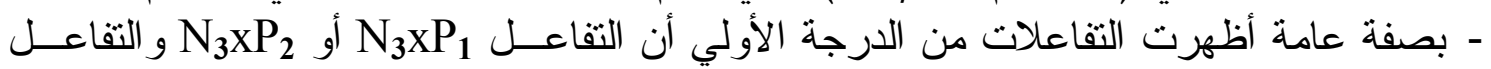
لو $\mathrm{N}_{3} \mathrm{LK}_{1}$

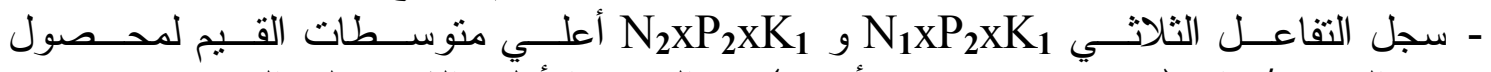

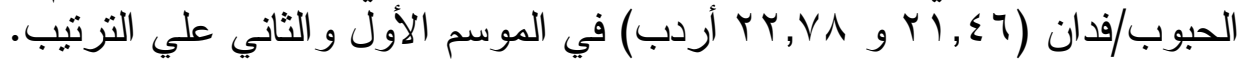

